DOI: $10.1515 / \mathrm{rpp}-2015-0068$

$\mathrm{PhD}$ in Pedagogical Sciences, Assistant Professor, MARYNA BOICHENKO Sumy State Pedagogical University named after A. S. Makarenko, Ukraine Address: 87 Romenska St., Sumy, 40002, Ukraine E-mail: marinaver18@yandex.ru

\title{
TALENT MANAGEMENT PROGRAMMES AT BRITISH, AMERICAN AND CANADIAN UNIVERSITIES: COMPARATIVE STUDY
}

\begin{abstract}
The article deals with the peculiarities of talent management programmes implementation at the top British, American and Canadian universities. The essence of the main concepts of research - talent and talent management - has been revealed. Talent management is referred to as the systematic attraction, identification, development, engagement, retention and deployment of those individuals who are of particular value to an organization, either in view of their "high potential" for the future or because they are fulfilling business/ operation-critical roles. The factors that drive the development of talent management at the universities have been defined. The benefits that can be obtained as a result of talent management programmes implementation in higher education institutions have been pointed out. The differences in talent management programmes implementation at the universities of Great Britain, the USA and Canada have been found out. These differences depend mainly on the human resources policy of the institution represented in its strategic plan. It has been concluded that most top British and American higher education institutions run talent development programmes, but the target categories and forms of their implementation greatly differ. Canadian universities in the human resources policy focus on professional development of staff and faculty, but do not have special talent management programmes. Progressive conceptual ideas of foreign experience that can be used in practice of Ukrainian universities have been considered.

Key words: higher education, human resources, talent management, talent management programmes, British, American and Canadian universities, talent development, staff professional development.
\end{abstract}

\section{INTRODUCTION}

In modern conditions of global competitiveness higher education institutions face a lot of challenges, one of which is development of teachers' potential, their talents, namely, nurturing future leaders within pedagogical staff of the university. Though development of talent in higher education institutions of the developed foreign countries has been an issue of the university policy for more than ten years, at Ukrainian universities there are no clear institutional strategies concerning talent management. In this context the study of foreign experience of talent management programmes implementation at British, American and Canadian universities is of particular relevance.

\section{THE AIM OF THE STUDY}

The aim of the study is to characterize talent management programmes at British, American and Canadian universities and consider the possibilities of use of progressive conceptual ideas in foreign experience in practice of Ukrainian universities. 


\section{THEORETICAL FRAMEWORK AND RESEARCH METHODS}

The study is based on the conceptual provisions of human resources theory according to which talent management is a set of staff management tools, which allow organizations to attract, engage, develop and retain employees who make significant contributions to the development of the organization.

The analysis of the problem is made on the basis of fundamental and applied research of the theorists and practitioners of human resources and talent management in the sphere of higher education, in which considered problem is discussed versatile and systemically.

In order to find out peculiarities of talent management programmes implementation in the studied countries we analyzed the websites of leading British, American and Canadian universities which contain detailed information of their talent management programmes.

Research methods are terminological analysis with the help of which the essence of the approaches to talent management at the universities in different countries has been defined; comparative analysis aimed at defining common features and differences in the implementation of talent management programmes at British, American and Canadian universities and finding the ways of using foreign experience in Ukrainian higher education institutions.

\section{RESULTS}

Talent management in modern conditions is a key strategy of any organization, as the success of its functioning depends much upon the intellectual and creative potential of its employees. Before finding out the peculiarities of talent management programmes implementation at the universities of the foreign countries we consider it expedient to define the basic concepts that reveal the essence of the studied process, in particular - talent and talent management.

According to the definition, given by Chartered Institute of Personnel and Development (CIPD), talent consists of those individuals who can make a difference to organizational performance either through their immediate contribution or, in the longerterm, by demonstrating the highest levels of potential (CIPD, 2012). In its turn, talent management is the systematic attraction, identification, development, engagement, retention and deployment of those individuals who are of particular value to an organization, either in view of their "high potential" for the future or because they are fulfilling business / operation-critical roles (CIPD, 2012).

As any other organization, higher education institutions are administered according to the same principles that are relevant in the sphere of business organizations. That is why talent management approach which is widely used in firms and enterprises is popular in educational institutions of different levels.

As the focus of our research lies in the sphere of higher education we find it necessary to point out the factors that drive the development of talent management at the universities. They include increasing competition among higher education institutions (both public and private); necessity of defining talent among pedagogical staff; need to address staffing issues in future; problems of recruitment and retention universities face; demographic changes and changes in external labor markets; lack of qualified personnel; weak utilization of the experience and capacity of the existing workforce.

The importance of developing effective strategies for talent management researchers P. Capelli and J. Keller explain by the benefits that can be obtained as a result of their implementation, in particular: reducing the cost of employing staff due to a reduction in staff turnover; effective knowledge management and knowledge transfer; provision of modern services and products; creation of competitive advantage; reducing employment risks; improving relationships with customers (consumers of educational services); holding personnel potential at the appropriate level (Capelli, Keller, 2014). 
It should be noted that talent management is one of the functions of human resources department which is a structural unit of any British, American or Canadian university. At the same time not every higher education institution considers talent management the priority of its activity. According to A. Hewett's survey that covered about 80 US universities, only $36 \%$ of higher education institutions consider talent management one of the five top strategies of the university development (Hewett, 2012).

Taking into account the fact mentioned we choose for our study top universities of Great Britain, the USA and Canada.

Among the British universities the focus was given to such higher education institutions as University of Cambridge, University of Oxford and Imperial College London.

In particular, University of Cambridge provides wide opportunities for training and development for different target categories: academic staff, administrators and support staff, leaders and managers and research staff. In the context of talent management, special focus is given to development programmes for leaders and managers of different levels. They include short courses and online modules for personal development of leaders; administrator development programme, emerging research leaders programme, strategic development programme, aspiring leaders programme, head of institution programme, senior leaders' succession programme (University of Cambridge, 2015). In our opinion, participation in these programmes enables developing leadership potential of university staff and solving the key tasks of talent management - identify, develop and retain talent.

In Imperial College London over the last six years there have been implemented several targeted talent development programmes for a wide range of staff: Horizon (2009-2010), Pegasus (2010-2011) and Meridian (2013-2014; 2014-2015). Each programme covers different categories of staff including not only academics and departmental administrators, but also human resources, ICT and finance staff. Current programme "Meridian" is aimed at "providing good candidates for succession to senior roles by improving internal candidates' capability to step up and fill these key roles; increasing diversity at a senior level; mitigating risk by having people ready to step into key roles if the current holders become unavailable; improving retention by making people feel valued and invested in by the College" (Imperial College London, 2015). The programme suggests such forms of activities arranged in core modules, some of which are delivered in collaboration with the Business school, namely, contribution to key College projects; shadowing / visits to external organizations; lunchtime master classes; peer and individual support through action learning sets and 1 to 1 coaching.

Unlike previous two higher education institutions, University of Oxford has not implemented talent development programmes yet, but according to its strategic plan the university has to "strengthen support arrangements for all groups of staff, including courses for personal and professional development, mentoring and the use of regular opportunities to review progress and promote career development" (University of Oxford, 2015). It is also noted that the university's new priority is developing leaders' potential that "require enhanced leadership and management capability and effective succession planning" (University of Oxford, 2015).

Among the American universities we have made an attempt to analyze such institutions as Harvard, Yale and Columbia Universities.

As described above British universities, Harvard University also recognizes the importance of internal talent development. This purpose serves Harvard Leadership Development Program, which consists of five multiday programs "designed specifically for different segments of the university's talented workforce - support staff, individual 
contributors, supervisors, mid- to senior-level managers and university executives, addressing the leadership development needs of each group" (Harvard University, 2015).

In our opinion, in the context of the researched problem deserves attention "The Harvard Bridge Program", an adult education and training program, which is open to all Harvard University staff and faculty. This programme is aimed at "providing employees with the skills and confidence to excel in their current roles, meet their career goals, and prosper in their personal lives". The classes include such directions as academic writing, communication skills for post-docs, business writing, career exploration, computer skills, English for speakers of other languages (ESOL), high school diploma preparation, office skills, presentation skills, speaking and listening, TOEFL preparation, etc. (Harvard University, 2015).

Yale University provides a wide range of programmes for talent development. It should be noted that talent development at this university is one of the top priorities of the human resources policy. There is "The Organizational Effectiveness Department" that is a special structure engaged in attracting, retaining and developing talent. There are three types of programmes at Yale: 1) manager development courses (C\&T Performance Management Training for Supervisors, Great Manager Program, InsideOut Coaching, Managing for Results, Managing at Yale Essentials, etc.); 2) professional development courses (Career Power: Optimizing Your Career Development, Leading through Change, Leading with Influence, Mastering Difficult Conversations, Navigating Conflict, Project Management for Yale Professionals); 3) staff development courses (Building Your Professional Network, Embracing Change, Exploring Career Satisfaction, Goal Setting and Feedback for NONSUPERVISORS, Managing Your Career, etc.) (Yale University, 2015).

Unlike Harvard and Yale, talent management is not an issue of special attention of human resources department at Columbia University. Nevertheless, Learning \& Development team helps "support the personal and professional development of faculty and staff at various stages of their career through a variety of live training programs and online resources" (Columbia University, 2015). There are several professional development programmes, which are targeted at all faculty and staff (e.g. New Hire Orientation - for newly employed staff) and separately for managers (Navigating the University as a New Manager, Managing Performance at Columbia University).

It is common knowledge that staff promotion is one of the constituents of talent management process. In this direction Columbia University has made important steps. One of the key issues of Managing Staff Promotions and Lateral Transfers policy is "to support an environment that values career mobility and encourages staff members who express an interest, and have the abilities, to pursue appropriate vacancies to foster their career development". So, Columbia University "establishes a university-wide process for effectively managing the movement of staff both among and within schools and departments for approved positions" (Columbia University, 2015).

Unlike at British and American higher education institutions, functions of human resources departments at Canadian universities do not include talent management. The analysis of websites of several top Canadian universities (University of Toronto), the University of British Columbia), University of Alberta), Simon Fraser University) has shown that these higher education institutions pay much attention to staff and faculty professional development and offer different professional development programmes, but they are not aimed at developing skills and competences of staff members who have potential to take leadership position in future.

CONCLUSIONS

Summarizing the facts mentioned we would like to conclude that most top British and American higher education institutions run talent development programmes, but the target 
categories and forms of their implementation greatly differ. Leaders of implementation of talent management programmes, in our opinion, are Imperial College London and Yale University. It should be noted, that human resources policy at the studied British and American universities include the statements about the necessity of attracting, engaging, developing and retaining talent. Unlike the above mentioned universities analyzed Canadian ones have not implemented the talent management programmes yet, at the same time they emphasize the importance of staff and faculty professional development that are aimed at improving skills necessary in everyday teaching / research / management activities.

In the framework of our study the following progressive conceptual ideas of foreign experience can be used in practice of Ukrainian universities: establishing human resources department at each Ukrainian university; developing human resources policy that would includ talent management strategies; developing and implementing talent management / professional development programmes aimed at training staff and faculty of different levels. The prospects for further research can be connected with technological aspects of implementation of talent management programmes at the universities of Great Britain and the USA

\section{REFERENCES}

1. Capelli, P., Keller, J. (2014). Talent Management: Conceptual Approaches and Practical Challenges. Annual Review of Organisational Psychology and Organisational Behaviour, No 1, pp. 305-331.

2. CIPD. (2012). Talent Management: An Overview Resource Summary. Retrieved 27.08.2015 from : http://www.cipd.co.uk/hr-resources/factsheets/talent-management-overview.aspx.

3. Columbia University. Managing Staff Promotions and Lateral Transfers. (2015). Retrieved 02.09.2015 from : http://policylibrary.columbia.edu/managing-staff-promotionsand-lateral-transfers.

4. Harvard University. Leadership development. (2015). Retrieved 08.09.2015 from : http://hr.harvard.edu/leadership-development.

5. Hewitt, A. (2012). 2012 Higher Education Survey: The State of Human Resources Effectiveness. Retrieved 10.09.2015 from : http://www.aonhewitt.com.

6. Imperial College London. The Meridian Leaders Programme. (2015). Retrieved 08.09.1015 from : http://www3.imperial.ac.uk/staffdevelopment/talentdevelopment/meridian.

7. Simon Fraser University. Human Resources. Learning and Development. (2015). Retrieved 10.09.1015 from : http://www.sfu.ca/human-resources/learning-development.html.

8. The University of British Columbia. Working at UBC. (2015). Retrieved 11.09.1015 from : http://faculty-staff.ubc.ca/faculty-staff/.

9. University of Alberta. Faculty and staff. (2015). Retrieved 12.09.1015 from : https://uofa.ualberta.ca/faculty-and-staff.

10. University of Cambridge. Leadership Development Framework. (2015). Retrieved 10.08.1015 from : http://www.ppd.admin.cam.ac.uk/information-leaders-andmanagers/leadership-development-framework.

11. University of Oxford. Strategic Plan. (2015). Retrieved 14.08.1015 from : http://www.ox.ac.uk/about/organisation/strategic-plan/personnel.

12. University of Toronto. Human Resources and Equity. Organizational Development \& Learning Centre. (2015). Retrieved 10.09.1015 from : http://www.hrandequity. utoronto.ca/about-hr-equity/ODLC.html.

13. Yale University. Organizational Effectiveness \& Staff Development. (2015). Retrieved 17.09.1015 from : http://www.yale.edu/hronline/hr-mission.html. 